\title{
Academic Quality and Ranking: A Methodical Approach for Departmental Ranking of Colleges and Universities in Saudi Arabia
}

\author{
Abdulmonem Alzalabani ${ }^{\mathrm{a}}$, Reji D. Nair ${ }^{\mathrm{b}}$ \\ ${ }^{a}$ Deputy Managing Director, Yanbu University College, Saudi Arabia, ${ }^{b}$ Faculty, Business Department, Higher \\ Colleges of Technology, UAE
}

\begin{abstract}
The importance of academic ranking as a marketing strategy in the educational market is evinced even in Middle East countries in recent times. The paper attempts to develop an academic quality assessment model using a composite index which can be applied to colleges and universities in Saudi Arabia. The criteria applied in the model are based on the quality indicators used by major global ranking agencies in the field such as Shanghai ranking, THES ranking and so on. Using the department-level data collected from Yanbu Industrial College the model is demonstrated and departments are rated and ranked. The academic quality index and its indicator indices are useful to identify the department level strengths and weaknesses.
\end{abstract}

Key Words: Ranking; Quality; Accomplishment; Student; Achievement, College

(C) 2014 Beykent University 


\section{Introduction}

There are differences in criteria and strategy used to rank higher learning institutions throughout the world. However, it is one of the methods used to evaluate the educational outputs and thereby used extensively to compare higher learning institutions. The measurement of academic quality is basically focused on educational outputs and different criteria emphasize different weights to the selected indicators. Over the years there are tremendous improvements and diversification including sophistication of the approach to ranking. The independent rankings not only give various stakeholders with the essential of unbiased educational information, but also help the policy makers with necessary analytical tools (Linn, 1993). Quality assessment of higher learning institutions is a difficult task and it requires application of diverse methods and techniques. Well-designed criteria are backed by rigorous methodological instruments. But, different ranking agencies are following different methodologies having different perspectives and sometimes it become controversial as well due to quantification of subjective elements (Casper, 1996), and enduring as a result of lack of other publicly attractive methods for comparing institutions (Sanoff, 1998).

The objective of the paper is to develop a rational method of measurement of academic quality ranking at the higher learning institutions in Saudi Arabia. There are many agencies that rank the colleges and universities throughout the world, which uses diverse indicators and methods. However, most of these criteria neglect the local conditions and environment especially at the college level. The present paper is attempting to develop an academic quality index through which objectively rate and rank the institutions and departments. This kind of rating is anticipated to promote a positive competition among the colleges and departments, which will further improve the quality and competitiveness in the areas of their specialization.

The specific objectives of the paper are the following.

To review the existing methods of academic quality ranking criteria world-wide;

To develop an objective academic quality measurement system, which can be adaptive at the college level in Saudi Arabia; and

To demonstrate the rationality and feasibility of the new system (Academic Quality Index) at the college level.

The study uses major academic ranking criteria presently applied throughout the world in ranking universities and colleges to develop the innovative model. This model is based on a composite index, which is a culmination of several indicators coming under broad criteria of measurement. Data collected at the department level from Yanbu Industrial College (YIC) in Saudi Arabia in the academic year 2012-13 is used in the paper. 
The paper is divided into six sections including the introduction; objectives, methods and scope of the study are briefed in section-1. Section-2 discusses about the Yanbu Industrial College, its academic departments, their vision and missions. Important ranking institutions such as Shanghai rating, THES ranking, CHE ranking and Asia week ranking, and its criteria, indicators and assigned weights are reviewed in section-3. The review in section-3 helped to extract quality criteria such as students' achievement, faculty accomplishment, and institutional academic resources, which are discussed in section-4. Section-5 details the academic quality ranking model, its criteria, indicators and assigned weights. Using department level data the model is demonstrated and estimated different indicator indices including academic quality index in section-5. Final section concludes the findings of the study.

\section{Yanbu Industrial College}

Yanbu Industrial College (YIC), an affiliate of the Royal Commission for Jubail and Yanbu was established in 1989 to provide Saudi nationals with the technical, scientific and academic skills required by the industrial and other economic sectors it serves. The college is the prime technical training institution under the auspices of Colleges and Institutes Sector of Royal Commission at Yanbu. The College is located in the Yanbu industrial city, about $350 \mathrm{~km}$ north of Jeddah on the Red Sea side. YIC is equipped with modern instructional media such as computer labs, audio visual aids, well-equipped laboratories and technical workshops.

The Vision of the College is to prepare young Saudis for middle and higher level career positions in industry, commerce and government by providing appropriate knowledge and skills in all programs offered. YIC has eight important departments in this direction, which all offers Associate Degree, Bachelor degree, and diploma programs in the areas of specialization. Department of Chemical Engineering Technology (CHET) offers unique instructional programs at its associate and bachelor levels by blending chemical engineering and technology courses, well designed to cater the growing needs of the Kingdom in petroleum and petrochemical industries. The Electronics and Instrumentation Engineering Technology (EIET) department's programs meet the global standards and are accredited by the Accreditation Board of Engineering and Technology (ABET). Students are exposed to modern concepts in the realm of process control and instrumentation, installation, troubleshooting and maintenance of instrumentation, and electronics equipment systems.

The Electronics Power and Engineering Technology Department (EPET) have outstanding facilities such as power system simulation lab, communication lab, process control lab, net working lab, etc. The Information Communication Technology Department (ICT) seeks to combine excellence in education and research with an ultimate aim to provide IT services to industry, commerce and government organizations. The department is facilitated with fourteen computer labs which include specialized labs, computer networking, PC troubleshooting and maintenance and software application development. The Mechanical Engineering Technology Department (MET) offers programs in manufacturing technology and mechanical maintenance 
technology at associate degree level, and applied mechanical engineering technology at the bachelor degree level. The Industrial Management Technology (IMT) Department, which was established in 1996 is offering business studies program in office management, materials management and accounting and finance at associate degree level along with baccalaureate programs in management (Since 2005) and accredited by the ACBSP.

The General Science Department (GS) is equipped with physics labs, chemistry labs and computing labs. Even though it does not offers any programs of its own, if offers several courses under regular programs of other departments in various disciplines such as mathematics, statistics, physics, chemistry, Islamic studies, and Physical Education. The Geomatics Engineering Technology Department (GET) is the synergy of multiple disciplines including surveying, Geographic Information System (GIS), remote sensing, photogrammetry, cartography, Global Positioning System (GPS) and geodesy. The new department of Mechatronics is in operation recently and is developing various programs in the field. Mechatronics refers to a design methodology that encompasses a range of subjects such as macro and micro machinery, sensors, instrumentation technology, drive and actuator technology, computer based real time microprocessor systems, and real time software to enhance systems performance and improve quality of products.

Table: 1 Vision and Mission of YIC Departments

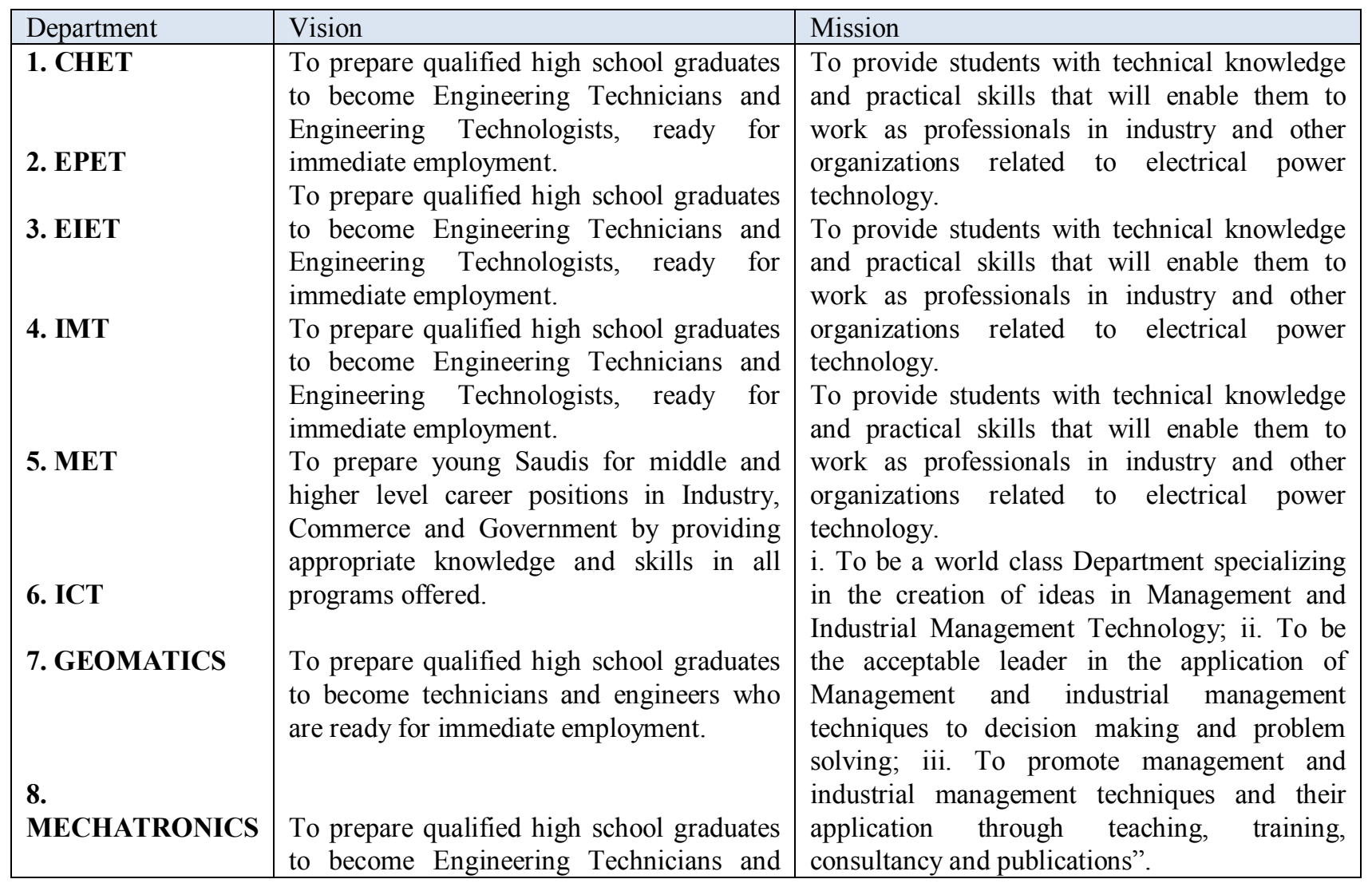




\begin{tabular}{|c|c|c|}
\hline Table continued & $\begin{array}{l}\text { Engineering Technologists, ready for } \\
\text { immediate employment. } \\
\text { The Geomatics Engineering Technology } \\
\text { Program (GET) at YIC will be a leader in } \\
\text { engineering education in Saudi Arabia and } \\
\text { stay competitive at the cutting edge of } \\
\text { technology through the excellence of its } \\
\text { faculty, staff, students, facilities and } \\
\text { programs. } \\
\text { To be leading research and educational } \\
\text { Mechatronics Technology Department in } \\
\text { the Kingdom of Saudi Arabia, offering } \\
\text { programs with emphasis on co-op training, } \\
\text { industrial partnerships, entrepreneurial } \\
\text { research activities and integration of cutting } \\
\text { edge technology through the excellence of } \\
\text { our faculty, staff, students and facilities. }\end{array}$ & $\begin{array}{l}\text { The Mechanical Engineering Technology } \\
\text { Department (MET) at YIC will be a leader in } \\
\text { engineering education in Saudi Arabia and stay } \\
\text { competitive at the cutting edge of technology } \\
\text { through the excellence of its faculty, staff, } \\
\text { students, facilities and program. } \\
\text { To provide students with technical knowledge } \\
\text { and practical skills that will enable them to } \\
\text { work as professionals in industry and other } \\
\text { organizations related to electrical power } \\
\text { technology. } \\
\text { To maintain a viable, efficient and relevant } \\
\text { academic unit providing high level } \\
\text { undergraduate and continuing education in } \\
\text { Geomatics, suitable for productive professional } \\
\text { and technical careers with principal emphasis } \\
\text { on spatial data collection techniques, digital } \\
\text { mapping, and spatial analysis using geographic } \\
\text { information technology while constantly } \\
\text { working to build Geomatics into a discipline of } \\
\text { increased recognition and reward. } \\
\text { To impart high quality engineering education } \\
\text { and prepare young Saudis as engineers for } \\
\text { leadership in industry, business, academia and } \\
\text { government. }\end{array}$ \\
\hline
\end{tabular}

Source: YIC (2013)

YIC is developing and implementing various academic and research programs in collaboration with local stakeholders as well as national and international organizations to achieve the stipulated vision and missions. Department-wise vision and mission of the College is as given in Table: 1 .

\section{Review of Academic Ranking Criteria}

Webster (1986) defined academic quality ranking as, 'Arrangement of higher learning institutions, schools, or departments in the field of study according to some quantifiable academic quality criteria in numerical order according to their quality'. This definition gives ranking agencies the freedom to select the indicators and ultimately the ranking is based on subjectivist criteria chosen for ranking. Since multiple indicators are used for such ranking, it is possible to produce individual indicator based rankings as well as combined ones. If the ranking agencies follow some fundamental principles in their ranking it can produce positive signals for the educational sector (Clark, M, 2002). Such ranking will promote positive competition among the educational institutions and educators and will ideally maintain the quality.

The pioneer in the academic ranking of higher learning institutions was Higher Education of Shanghai Jiao Tong University. The first international meeting convened by UNESCO-CEPES (European Centre for Higher Education) in Warsaw in 2002 discussed all methodological issues of ranking higher learning educational institutions. Education experts and policy makers along with the representatives of publishing agencies attended this conference to develop conceptual foundations of such a ranking system. In 2004, 
under the auspices of UNESCO-CEPES another round of meeting was organized for the experts to analyze the strength and weakness of such a system and working groups are formed. As a result of these deliberations the first international conference on world-class universities (WCU-1) was held in China in 2005. The popularity of ranking has increased in multi-faceted manner in recent times.

The quality assurance practices and systems exists in each country plays an important role in the accreditation of its academic quality. The Higher Education Ranking plays an important role in the quality assurance systems throughout the world. There are around 20 ranking agencies world-wide, which rank universities and colleges on the basis of academic outputs. Different agencies use diverse indicators in its ranking and the weights allotted also differ. Among the different agencies involved in ranking the most important ones are discussed below.

\subsection{The Shanghai Ranking}

The Shanghai ranking does not have any indicator measured by surveys and all indicators are quantitative measures rather than qualitative ones; accordingly it avoids errors associated with qualitative indicators. The Shanghai ranking follows four important criteria such as quality of education, quality of institutions, research output and size of institution (IHE-SJTU, 2005). The indicator corresponds to the quality of education is the Alumni of the institution winning Nobel prizes and filed medals with a weight of $10 \%$. Quality of education comprises two indicators having equal weights $(20 \%)$ such as staff of the institution winning Nobel Prizes and field medals, and highly cited researchers in broad subject categories. Research output comprised two indicators including articles published, and articles cited with weights of $20 \%$ each. Last but not least criteria are the size of the institution and its indicator targets academic performance with size (weight of $10 \%$ ). For details refer Table: 2. The highest scoring institution is assigned a score of 100 and all other institutions are rated as a percentage of the top score.

Table: 2 Shanghai Ranking Indicators

\begin{tabular}{|l|l|l|}
\hline Criteria & Indicator & Weights \\
\hline $\begin{array}{l}\text { 1. Quality of } \\
\text { Education }\end{array}$ & Alumni of an institution winning Nobel Prizes and Field Medals & $10 \%$ \\
$\begin{array}{l}\text { 2. Quality of } \\
\text { Institution }\end{array}$ & Staff of an institution winning a Nobel Prize and Field Medals & $20 \%$ \\
3. Research & Highly cited researchers in 21 broad subject categories & $20 \%$ \\
Output & Articles published in Nature and Science & $20 \%$ \\
4. Size of & Articles in Science Citation index-expanded, Social Sciences citation & $20 \%$ \\
Institution & index, Arts \& Humanities citation index & \\
& Academic performance with respect to the size of an institution & $10 \%$ \\
\hline
\end{tabular}

Source: IHE-SJTU, 2005 


\subsection{Times Higher Education Supplement (THES) Ranking}

The THES ranking approach is based on six major criteria including peer review with weight of $40 \%$, research excellence with $20 \%$, size (quality) with $20 \%$, employer's view with $10 \%$, and international student and staff with 5\% weights each (THES, 2005). For details on each criterion refer Table: 3.

Academic research usually gets predominant position in the academic ranking; but in the THES ranking the research output contributes only $20 \%$ of the final score and is measured through average citation per staff. However, the Shanghai ranking criteria gives undue importance to world class research and it contributes around $80 \%$ of the weights. Except the size of institution all the indicators including Nobel prizes, field medals, and citations are constructed on the basis of pure research. The quality of teaching is measured in the THES ranking by the staff to student ratio and in the Shanghai ranking by the indirect measure that is the number of students winning Nobel Prizes and Field Medals.

Table: 3 THES Ranking Indicators

\begin{tabular}{|l|l|l|}
\hline Criteria & Indicator & Weights \\
\hline 1.Peer Review & $\begin{array}{l}\text { Opinions of 5,101 experts, of whom 41\% are in Europe, the } \\
\text { Middle East and Africa, 30\% in the Americas, and 29\% in the }\end{array}$ & \\
2. Research & $\begin{array}{l}\text { Asia-Pacific region } \\
\text { Excellence }\end{array}$ & $20 \%$ \\
3. Size & Staff-to-student ratio & \\
4. Employer's view & Quacquarelli Symonds (QS) asks major global and national & $10 \%$ \\
& employers across the public and private sectors which universities & \\
they like to hire from. Latest sample includes 1,471 people, with & \\
5.International & $43 \%$ in the Americas, 32\% in the Europe, and 25\% in the Asia- & $5 \%$ \\
students & Pacific & $5 \%$ \\
6. International staff & Number of international students at institution & \\
& Number of international staff who come from other countries & \\
\hline
\end{tabular}

Source: THES, 2005

\subsection{CHE Ranking}

The German Centre for Higher Education Development framed an innovative approach to the academic ranking known as the CHE ranking. The CHE ranking is different from all other rankings because it does not follow any quantification and it justifies its criteria that marginal differences in point score are misinterpreted as real differences (CHE, 2007). As shown in Table: 4, the CHE ranking follows eight major criteria including job market orientation, equipment, research, opinion, international orientation, study results, study location, students, and academia.

\subsection{Asia Week Ranking}

The Asia week ranking is based on the Asian universities and uses five criteria such as peer review, student selectivity, faculty resources, research and financial resources (Asia Week, 2000). The details of indicators 
and corresponding weights are briefed in Table: 5 . The highest scoring university will be given a rating of 100 and others are assigned points as a percentage of the highest score.

Table: 4 CHE Ranking Indicators

\begin{tabular}{|c|c|}
\hline Criteria & Description \\
\hline $\begin{array}{l}\text { 1. Job market and } \\
\text { career-orientation }\end{array}$ & $\begin{array}{l}\text { 1. The transition to the job market and the career orientation of the academic } \\
\text { studies are important orientation points. }\end{array}$ \\
\hline 2. Equipment & 2. CHE examined the quality of the equipment. \\
\hline 3. Research & $\begin{array}{l}\text { 3. It is determined by how much third party funding is available, where the most } \\
\text { PhD degrees are undertaken and published and how many patents have been } \\
\text { submitted. }\end{array}$ \\
\hline 4. Over all opinion & $\begin{array}{l}\text { 4. The future fellow students can give their opinion on the state of the study } \\
\text { conditions. The professors are also asked to name higher education institutions } \\
\text { for their subject. }\end{array}$ \\
\hline $\begin{array}{l}\text { Orientation } \\
6 \text {. Result of study }\end{array}$ & $\begin{array}{l}\text { 5. Where are foreign language degrees courses offered? How comprehensive is } \\
\text { the offered range of foreign languages? }\end{array}$ \\
\hline $\begin{array}{l}\text { 7. Study location and } \\
\text { higher education } \\
\text { institution }\end{array}$ & $\begin{array}{l}\text { 6. The average duration of studies and the average grade in exams are examined } \\
\text { amongst other things. } \\
\text { 7. An important question for prospective students: Where do I feel more } \\
\text { comfortable? }\end{array}$ \\
\hline 8. Students & $\begin{array}{l}\text { 8. The sizes of the area of studies and the combination of the student body can } \\
\text { also play a decisive role in the selection of a tertiary institution. }\end{array}$ \\
\hline teaching & $\begin{array}{l}\text { 9. First-year students are interested in the opinion of professors and students of } \\
\text { their faculty. }\end{array}$ \\
\hline
\end{tabular}

Source: CHE, 2007

\section{Quality Indicators}

If the ranking initiatives are to be effective and fruitful the criteria that we model and the indicators selected are to be rational. Generally the indicators of almost all ranking agencies fall in the following three categories.
i. Student achievements,
ii. Faculty accomplishments, and
iii. Institutional academic resources.

The details of each category including indicator, advantage and disadvantage of each indicator are briefed in Table: 6. A rational approach to ranking should consider three important elements such as inputs, processes and outputs. Academic resources can be used as inputs; processes include teaching quality and 
outputs covers effectiveness of graduates along with research outputs. Selection of indicators should also consider their objective and subjective nature, the latter is more relevant as far as surveys are concerned. For instance, objective measurement of teaching quality is not an easy task. These factors will influence the selection of indicators and ranking.

Table: 5 Asia Week Ranking indicators

\begin{tabular}{|l|l|l|}
\hline Criteria & Indicator & Weights \\
\hline 1. Peer Review & 1. Experts from Asian corporations and foreign universities to rate the & 20 \\
2. Student & academic reputation of Asian universities. & 25 \\
3. Faculty & 2. Number of first year students accepted out of the total applicants. & 25 \\
Resources & 3. Number of enrolled students out of the accepted students. & 20 \\
4. Research & 4. Median score of the first year students enrolled. & \\
5. Financial & 5. Full time teachers with PhD Degree & \\
resources & 6. Fulltime teachers with Masters and PhD Degree & \\
& 7. Median pay & \\
& 8. Per-teacher spending by the institution & \\
& 9. Student-teacher ratio. & \\
& 10. Citation in academic journal (ISI) & \\
& 11. Articles in peer-reviewed journals & \\
& 12. Papers presented in international conferences & \\
& 14. Research funding & \\
& 15. Graduate students & \\
& 16. Spending per student & \\
& 18. Internet bandwidth \\
& 19. Public computers and connection points & \\
& 20. Laboratory spending & \\
\hline
\end{tabular}

Source: Asia Week, 2000

As could be seen from the above four rating agencies' ranking, there are 36 closely related indicators, of which majority are diverse for different agencies. A comparison is made in Appendix Table and only five indicators are repeated by more than one agency. The frequency of rating in percent is shown in the last column of the table. Most of the indicators are unique and some are related and can be grouped under major categories. Indicators are spread across 11 broad categories and are based in part on existing institutional systems of measuring quality: quality of research, reputation surveys, human resources, beginning characteristics, material resources, outputs, learning process, etc.

As Linn (Meredith, 2004) pointed out selection of the indicators should be based on the following three principles.

i. Validity: The indicator measures what it is planned to measure.

ii. Reliability: The indicator should be consistent.

iii. Comparability: It is possible to compare across different institutions. 
Any ranking methodology in this regard should also prove with evident data. If sufficient data is available there are two applications; firstly, separate ranking for each indicator, and secondly, overall ranking by assigning weights to each indicator. Jamie Merisotis (2002) proposes the following types of ranking.

i. Unified ranking: Overall standard of an institution is combined in a single value, which is a combination of several weighted indicators.

ii. Discipline based ranking: Institutions are ranked on specific programs or subjects.

iii. Other ranking: Ranking without any specific characteristics.

Table: 6 Category of Academic Quality

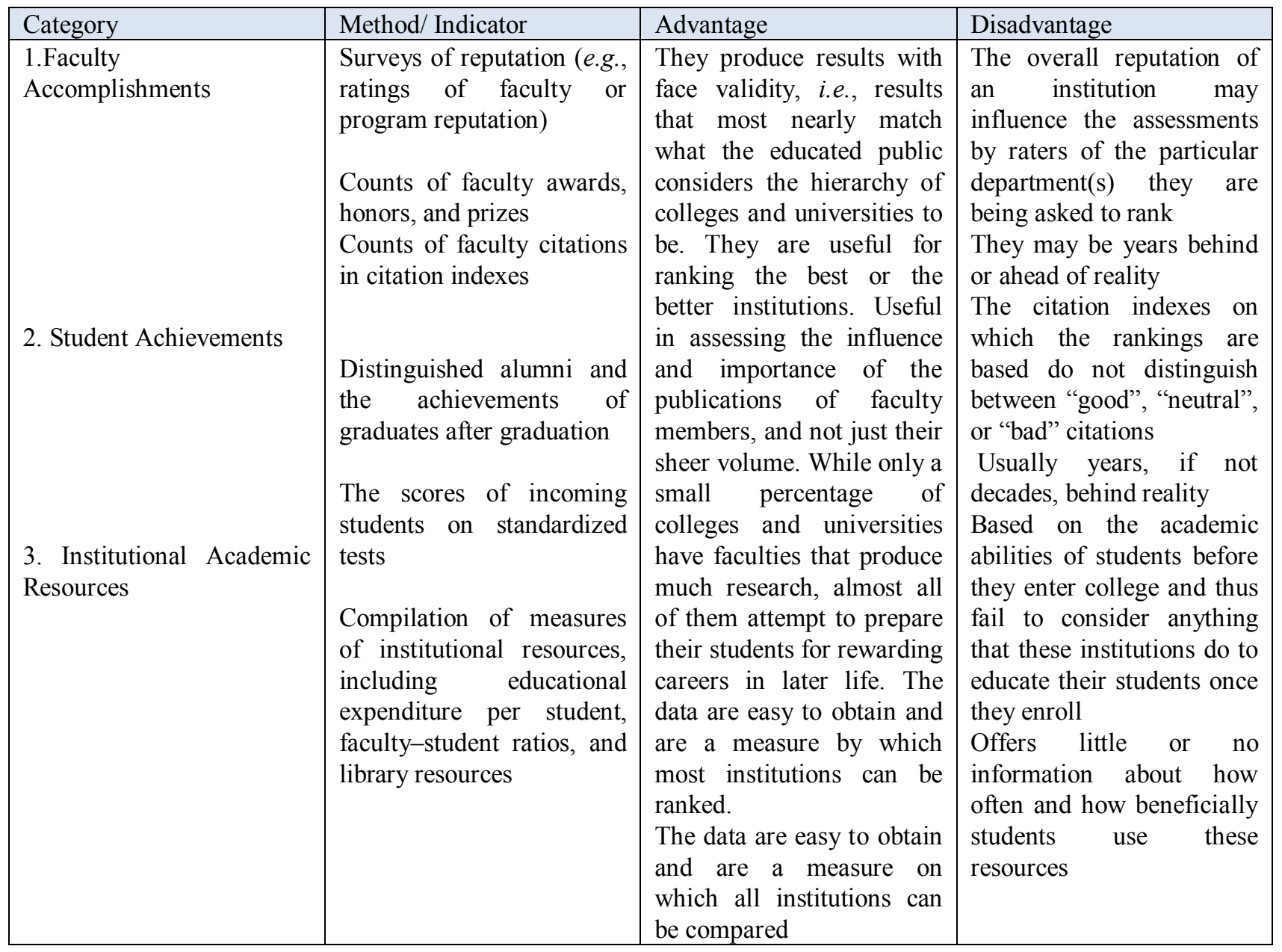

Source: Webster (1986)

From the foregone review of the criteria of major university rating agencies, it could be seen that all these indicators are basically classified into 7 major categories as outlined in Table: 7. It includes research, survey opinion, human resources, beginning characteristics, material resources, outputs, and learning process. Different agencies have given different ratings, but the average rating shows that $35 \%$ of the weights are given to quality of research followed by surveys (19\%), human resources (17\%) and so on. 
Most of the ranking agencies use the weight-and-sum approach wherein a weight is assigned to each indicator on the basis of the importance they assigned to it and combined it to an overall score (Swinski, 2002). The weights assigned are subjective and depends on the objective and discretion of the rating agency. Camilli and Firestone (2000) criticized the criteria of assigning weights and measurement of indicators due to inconsistency among different rating agencies. There are also criticisms on the grounds of neglect of institutional components and inter-relations between indicators of academic quality. Most of the intangible outcomes related to teaching and learning, resources and research are also issues of criticism in this regard. As discussed earlier any indicator selected should be abiding the principles of validity, reliability and comparability.

Table: 7 List of Academic Categories used in Ranking according to Weight

\begin{tabular}{|l|l|l|l|l|l|}
\hline Academic Categories & Weights & $\begin{array}{l}\text { Average } \\
\text { Rating }\end{array}$ \\
\cline { 2 - 6 } & Shanghai & Times & CHE* & $\begin{array}{l}\text { Asia } \\
\text { Week }\end{array}$ & \\
\hline 1. Quality of research & 80.0 & 20.0 & 25.0 & 16.5 & 35.0 \\
2. Reputation surveys & & 50.0 & 08.0 & 20.0 & 19.0 \\
3. Human resources & 10.0 & 25.0 & 17.0 & 15.0 & 17.0 \\
4. Beginning characteristics & & 05.0 & 08.0 & 25.0 & 10.0 \\
5. Material resources & & & 08.0 & 20.0 & 07.0 \\
6. Outputs & 10.0 & & 17.0 & 03.3 & 08.0 \\
7. Learning process & & & 17.0 & & 04.0 \\
\hline
\end{tabular}

* The CHE weights are calculated based on the number of indicators attached to each category.

Among the most important ranking agencies a good number are from the mass media, commercial publishing enterprises, and non-profit research centers. It shows the importance of academic ranking as a marketing strategy in the global and regional educational market. At the same time it is also an important element of strategic plans of the concerned universities. Among the indicators of academic ranking reviewed, majority of ranking agencies emphasize research indicators with higher weights than teaching and learning. It point to the disagreement between the institutional approaches vis-à-vis commercial orientations of ranking.

\section{Modeling Academic Quality Ranking Index}

From the foregone discussion it could be seen that a rational model of academic quality ranking would comprise three important criteria such as faculty accomplishment, students' achievement, and institutional academic resources and accomplishment (refer Table: 6). Among these three important elements the present model as depicted in Figure: 1 shows that it encompasses ten major indicators. Each indicator is assigned a weight of $10 \%$ and Faculty Accomplishment comprises two indicators, Students' Achievement three indicators, and Institutional Academic Resources \& Accomplishment five indicators. Accordingly the weights assigned to each criterion are 20: 30: 50 respectively as given in Figure: 2. 
Publications include research papers, articles, books, periodicals and manuscripts. Projects consist of YIC projects, external projects and students' graduation projects. Faculty involvement and accomplishment are directly measured through these two indicators.

Students' achievement embraces those indicators, which are the outcomes of learning in the college (YIC) such as graduation success rate (in the graduation semester), average cumulative grade point accumulated over the semesters (CGPA), and Graduates' employability rating (measured through a survey of graduates).

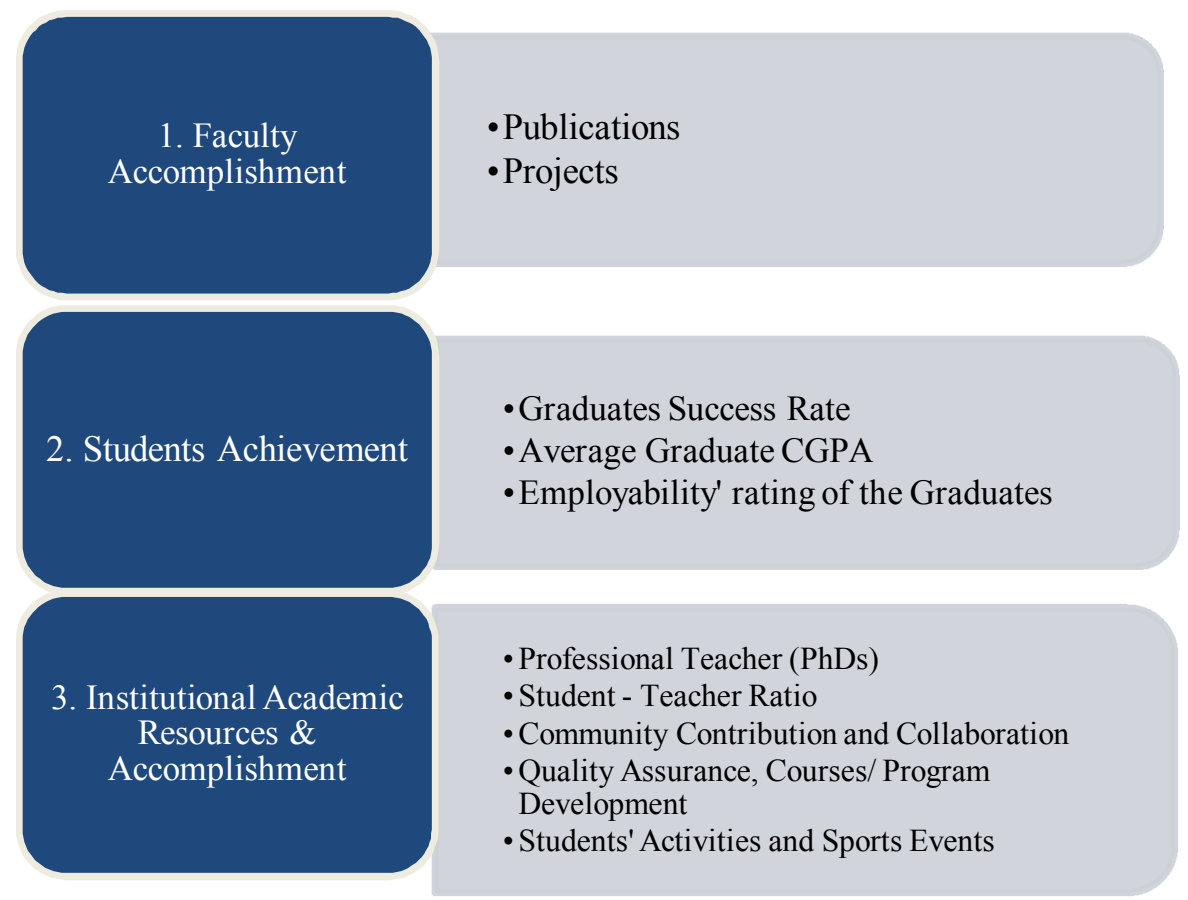

Figure: 1 Model of the Academic Quality Ranking

Institutional academic resources and accomplishment is a composite of proportion of professional teachers (PhD holders), ratio of students to teacher, and other academic achievements. Other academic achievements consist of community contribution and collaboration, quality assurance activities and program/ course development, and students' activities and sports events organized. Contribution to the community embraces seminars, trainings, workshops, and participation/ collaboration outside YIC; the latter include awards, conferences, community outreach programs, collaboration, consultation and memorandum of understanding signed.

Accreditation, benchmarking, quality assurance surveys, program surveys, faculty surveys, new courses, amendments, and new programs are the major components of quality assurance and program/ course development. Students' activities and sports events mainly consist of club activities, coop visits, sports events and other department activities. 


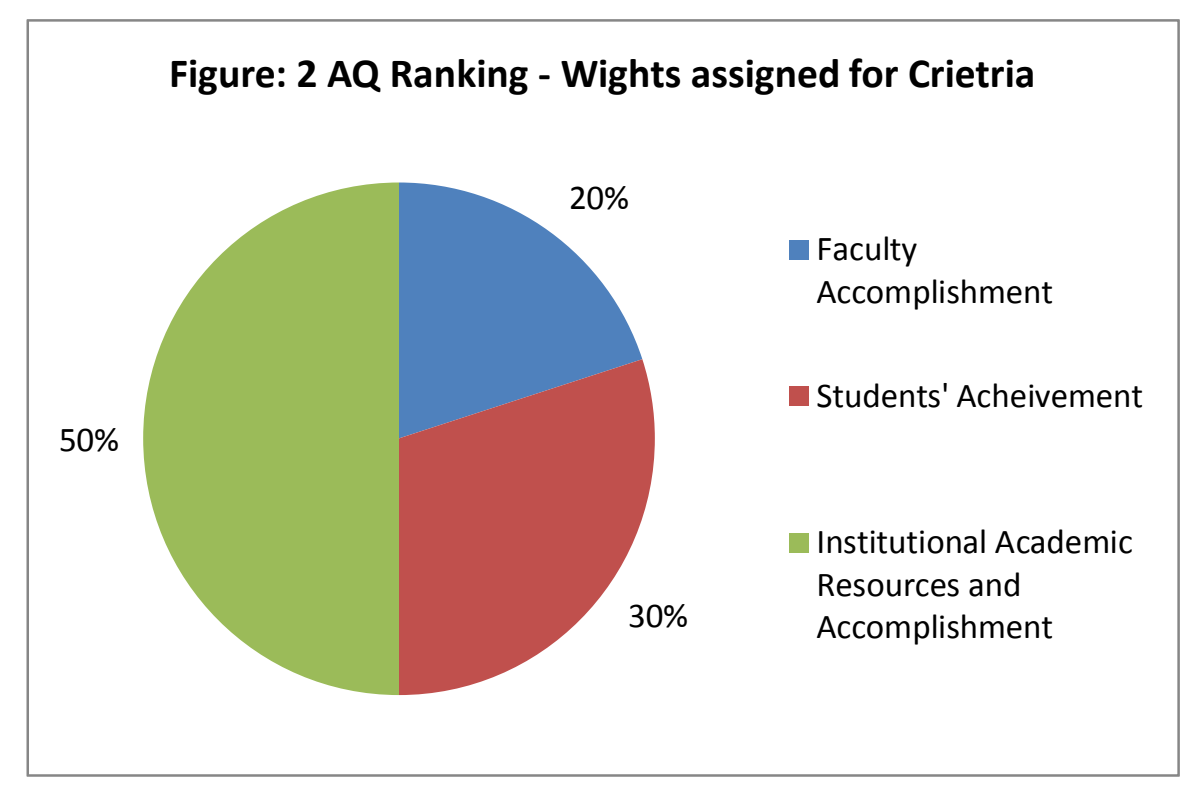

Figure 2: AQ Ranking

The above said ten indicators categorized under three criteria are used to develop Academic Quality Ranking Index (AQ Index). It is a composite index consisting of the average of the Faculty Accomplishment Index (FA Index), Students Achievement (SA Index), and Institutional Academic Resources and Accomplishment Index (IARA Index).

$$
A Q \text { Index }=\frac{(\text { FA Index }+S A \text { Index }+ \text { IARA Index })}{3}
$$

The value of the index ranges from zero to one, the latter being the highest value when indicator indices have scored maximum performances. Each of the three Criteria Indices is framed out from the corresponding indicator index using the following formulae.

$$
\text { Indicator index }=\frac{(\text { Actual Value }- \text { Minimum Value })}{(\text { Maximum Value-Minimum Value })}
$$

The actual value is the observed indicator value at the department level, minimum value is the lowest probable value of the concerned indicator and it is usually fixed as zero. Maximum Value is the highest indicator value observed among all departments in the college.

\subsection{Faculty Accomplishment Index}

Faculty Accomplishment is one of the three categories of the Academic Quality ranking in the present model. Faculty Accomplishment index (FA Index) is the average of the Publication index (Pub Index) and Project Index (Proj Index) framed out using the following formulae.

$$
F A \text { Index }=\frac{(\text { Pub Index }+ \text { Proj Index })}{2}
$$


The indicator indices of Pub Index and Proj Index are outlined using the forumulae-2. The details of the department-wise faculty accomplishments in 2012-13 are as mentioned in Table: 8 .

Table: 8 Department-wise Publication and Projects, 2012-2103

\begin{tabular}{|l|l|l|}
\hline Department & Publications & Projects \\
\hline 1. EIET & 22 & 17 \\
2. EPET & 8 & 12 \\
3. GS & 12 & 2 \\
4. IMT & 20 & 4 \\
5. MECHATRONICS & 0 & 0 \\
6. GEOMATICS & 5 & 1 \\
7. MET & 7 & 14 \\
8. CHET & 20 & 16 \\
9. ICT & 10 & 0 \\
\hline
\end{tabular}

Source: YIC, Academic Report, 2012-13

Department-wise Publication and Project Indices of YIC departments are as shown in Figure: 3. EIET department topped in both publication and project indices followed by CHET department.

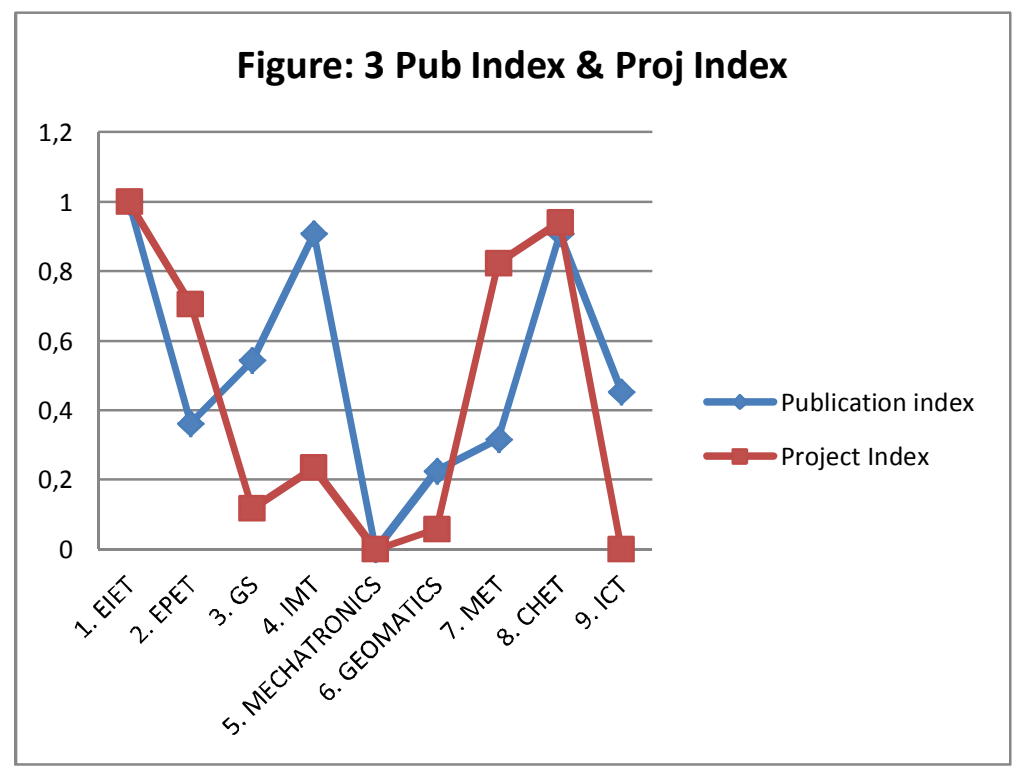

Figure 3: Pub Index\& Proj Index

The Faculty Accomplishment Index of YIC departments are as shown in Figure: 4. EIET department scored the maximum followed by CHET, IMT and MET departments in 2012-13. 


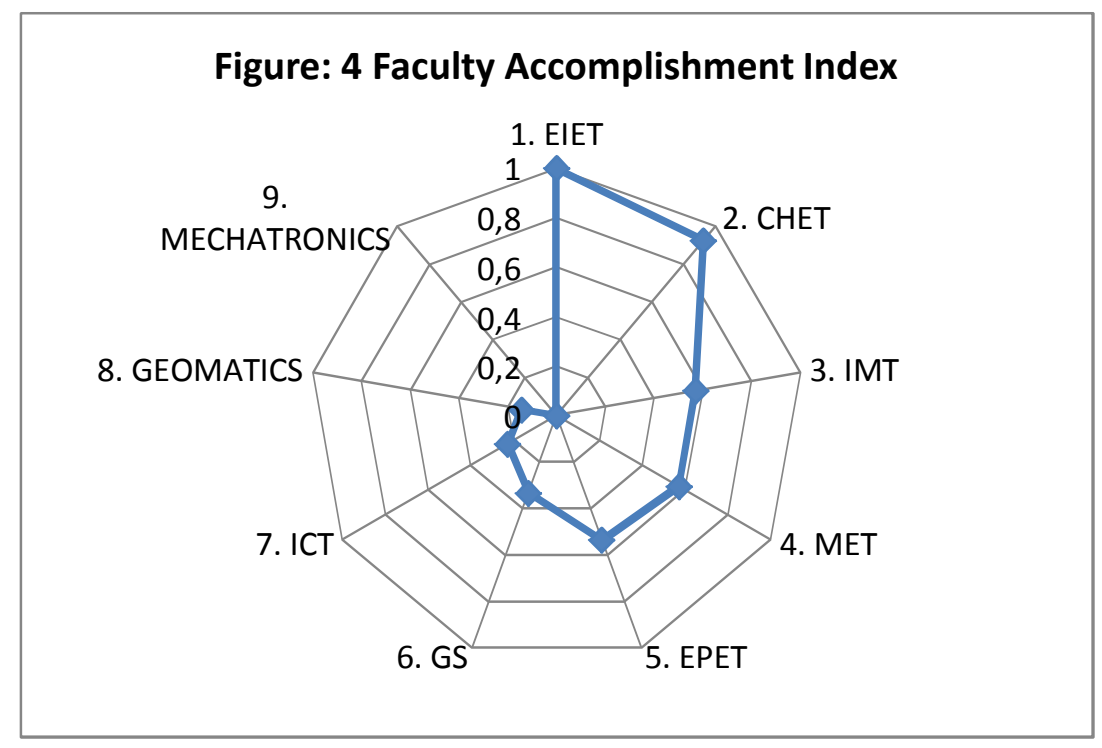

Figure 4: Faculty Accopmplishment Index

\subsection{Students' Achievement Index}

Students Achievement is the second criteria to measure the Academic Quality in the present model. Students Achievement Index (SA Index) is the average of the Graduate Success Rate Index (GSR Index), Average CGPA Index (CGPA Index), and Employability Rating of the Graduates Index (ERG Index).

$$
S A \text { Index }=\frac{(G S R \text { Index }+C G P A \text { Index }+E R G \text { Index })}{3}-----(4)
$$

The indicators indices of GSR index, CGPA index, and ERG index are measured using the formulae-2. The details of Students' achievement are as furnished in Table-9.

Department-wise CGPA index, GSR index, and ERG index are as shown in Figure: 5. CHET, MET, EIET, and EPET departments performed highly competitive way in a uniform manner over all the three indices.

The Students Achievement Index (SA Index) in YIC departments are as shown in Figure: 6. In almost all departments the students' achievement on all the three major dimensions are quite excellent. 
Table: 9 Department-wise Students’ Achievement, 2012-13

\begin{tabular}{|l|l|l|l|}
\hline Department & $\begin{array}{l}\text { Graduates Success } \\
\text { Rate }\end{array}$ & $\begin{array}{l}\text { Average CGPA of } \\
\text { Graduates }\end{array}$ & $\begin{array}{l}\text { Employability Rating of } \\
\text { the Graduates* }\end{array}$ \\
\hline 1. EIET & 91.01 & 2.31 & 93.20 \\
2. EPET & 91.85 & 2.19 & 93.20 \\
3. GS & 86.40 & 2.37 & N/A \\
4. IMT & 95.02 & 2.57 & 75.00 \\
5. MECHATRONICS & 0 & 0 & N/A \\
6. GEOMATICS & 81.65 & 1.83 & N/A \\
7. MET & 90.57 & 2.41 & 93.20 \\
8. CHET & 94.61 & 2.45 & 92.50 \\
9. ICT & 91.72 & 2.44 & N/A \\
\hline
\end{tabular}

* Employability rating of graduates are measured through a survey and the departments for which it is not applicable are shown as 'N/A'

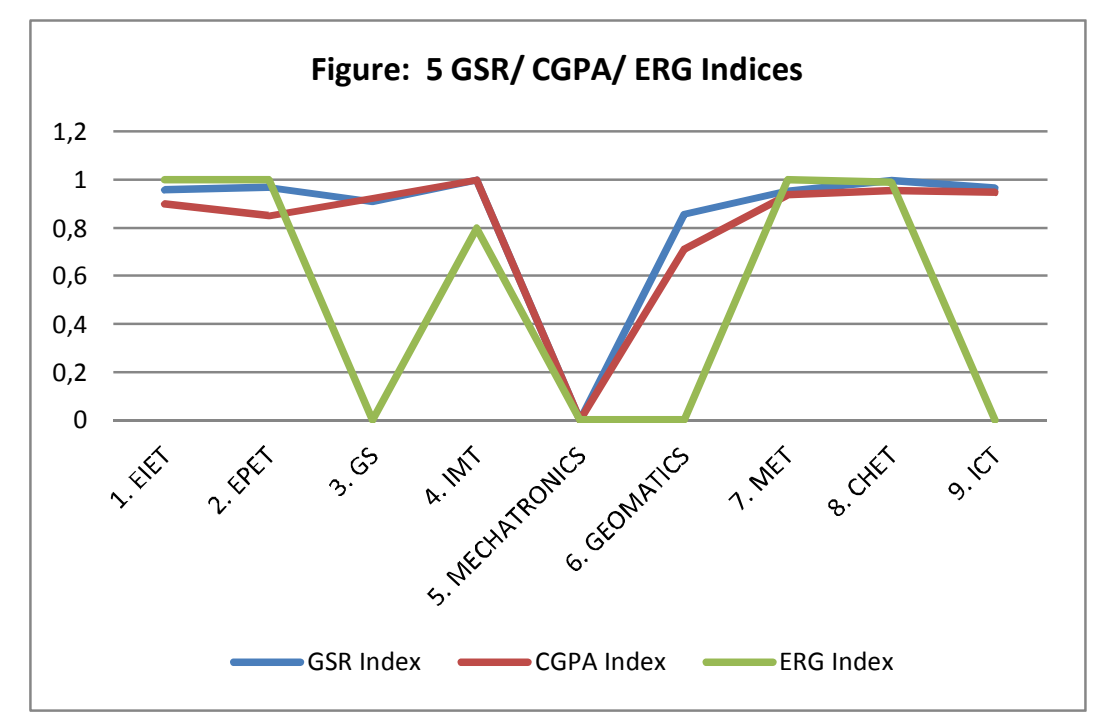

Figure 5: GSR/ CGPA/ERG Indices

\subsection{Institutional Academic Resources and Accomplishment Index}

The third component of Academic Quality Index measurement is the institutional academic resources and accomplishment. It contributes one-half of the weight of the AQ index. Institutional Academic Resources and Accomplishment Index (IARA Index) is the average of five indicators such as Professional Teacher Index (PT Index), Students-Teacher Ratio Index (STR Index), Community Contribution and Collaboration Index (CCC Index), Quality Assurance and Courses/ Program Development Index (QACPD Index), and Students Activities and Sports Events Index (SASE Index). 


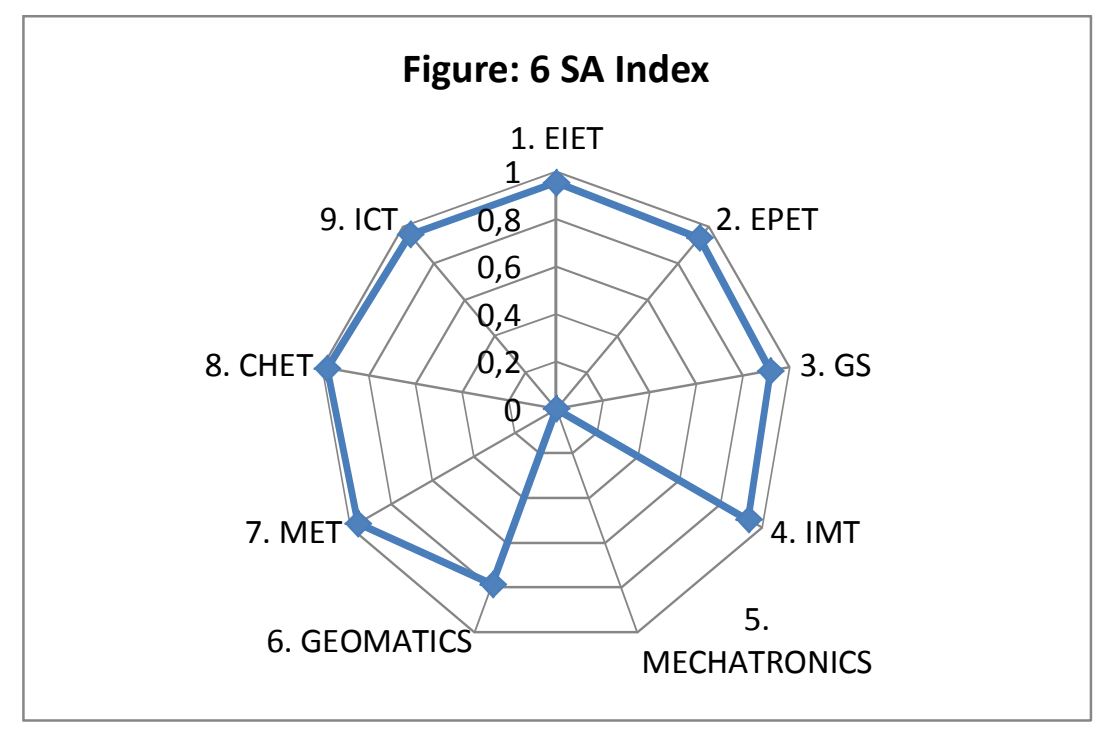

Figure 6: SA Index

$$
I A R A \text { Index }=\frac{(P T \text { Index }+S T R \text { Index }+C C C \text { INdex }+Q A C P D \text { Index }+S A S E \text { Index })}{5}---(5)
$$

The indicator indices of PT Index, STR Index, CCC Index, QACPD Index, and SASE Index are measured using the formulae-2. Department-wise details of institutional academic resources and accomplishment are briefed in Table: 10 .

Department-wise details of PT Index, STR Index, CCC Index, QACPD Index, and SASE index are as shown in Figure: 7. MET department scored the maximum for Professional teacher index, whereas CHET department lead the students-teacher ratio index. As regards community contribution and collaboration index GS department performed better than other departments. IMT department topped the list of departments in quality assurance and courses/ program development index. EIET department outpaced all other departments in students' activities and sports events.

The Institutional Academic Resources and Accomplishment Index (IARA Index) of YIC in 2012-13 is as shown in Figure: 8. The IARA index score of CHET department was the highest followed by EIET, GS, and IMT departments. 
Table: 10 Department-wise Institutional Academic Resources and Accomplishment, 2012-13

\begin{tabular}{|l|l|l|l|l|l|}
\hline Department & $\begin{array}{l}\text { Professional } \\
\text { Teachers } \\
\text { (PHDs) }\end{array}$ & $\begin{array}{l}\text { Students- } \\
\text { Teacher } \\
\text { Ratio* }\end{array}$ & $\begin{array}{l}\text { Community } \\
\text { Contributions } \\
\text { and } \\
\text { Collaborations } \\
\text { outside YIC }\end{array}$ & $\begin{array}{l}\text { Quality } \\
\text { Assurance \& } \\
\text { Courses/ } \\
\text { program } \\
\text { Development }\end{array}$ & $\begin{array}{l}\text { Student's } \\
\text { Activities and } \\
\text { sports events }\end{array}$ \\
\hline 1. EIET & 8 & 11.95 & 19 & 9 & 11 \\
2. EPET & 2 & 15.42 & 4 & 2 & 9 \\
3. GS & 12 & NA** & 22 & 7 & 6 \\
4. IMT & 7 & 9.26 & 9 & 32 & 5 \\
5. MECHATRONICS & 1 & 0 & 0 & 0 & 0 \\
6. GEOMATICS & 0 & 17.33 & 7 & 3 & 1 \\
7. MET & 13 & 18.44 & 5 & 0 & 5 \\
8. CHET & 12 & 21.77 & 13 & 15 & 9 \\
9. ICT & 2 & 2.83 & 18 & 6 & 4 \\
\hline
\end{tabular}

* The highest ratio is 21.77 and optimum class size being 30, it is anticipated that higher student-teacher ratio is a positive indicator of the resource use efficiency in the college.

** GS Department does not have its own graduate or associate degree programs.

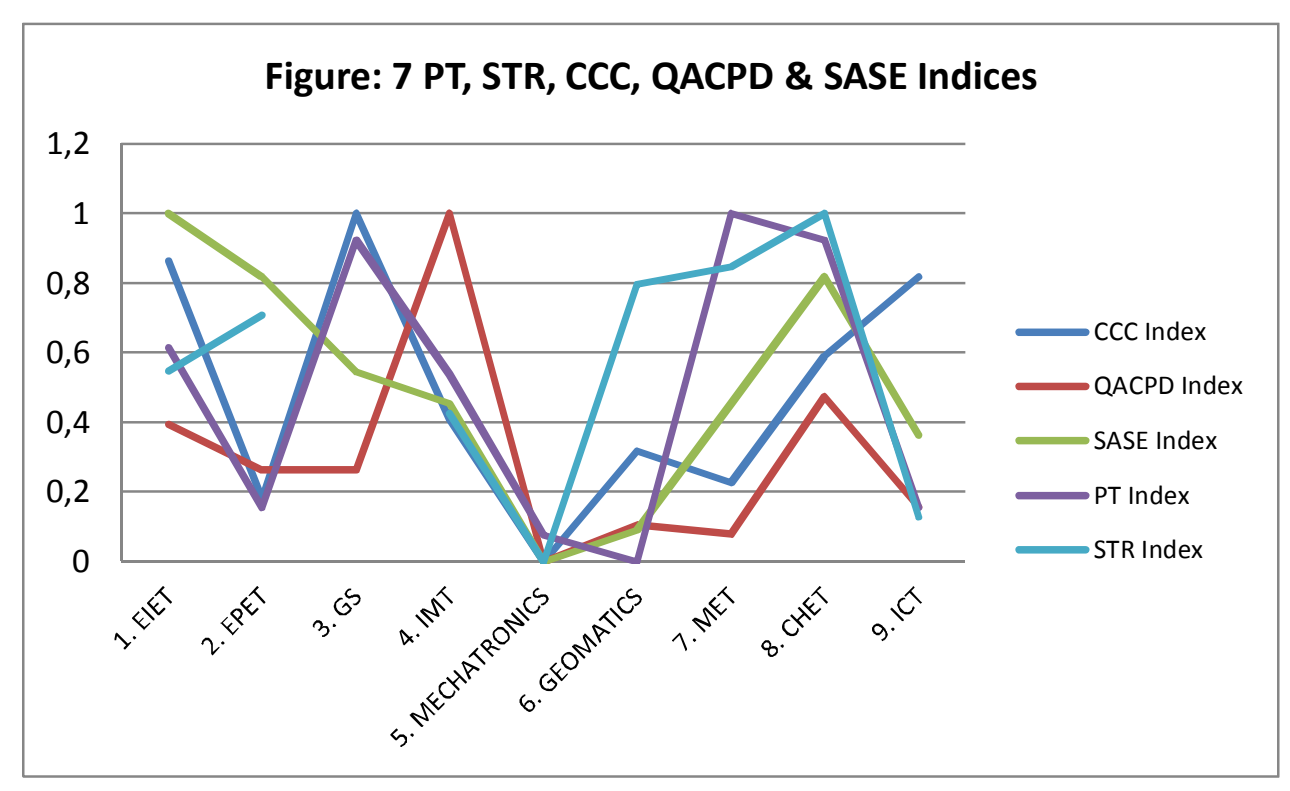

Figure 7: PT, STR, CCC, QACPD and SASE Indices 


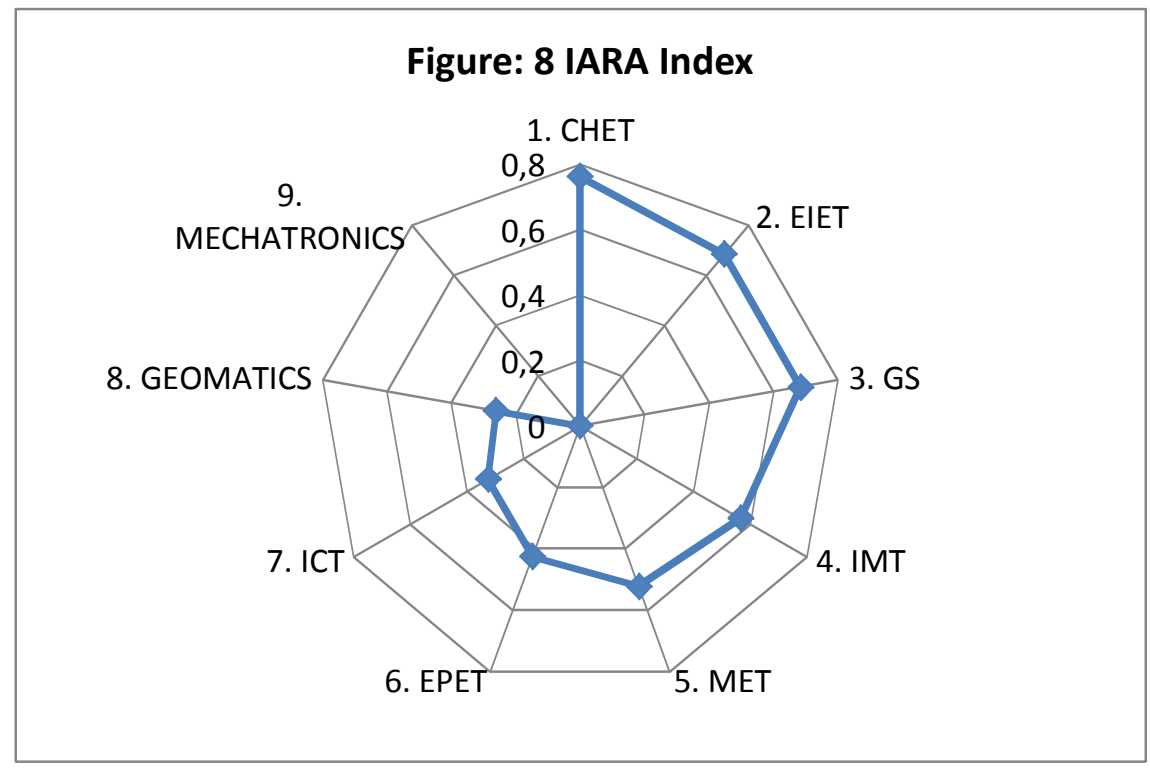

Figure 8:IARA Index

\subsection{Academic Quality Index}

Academic Quality Index (AQ Index) is an average of Faculty Accomplishment Index (FA Index), Students' Achievement Index (SA Index) and the Institutional Academic Recourses and Accomplishment Index (IARA Index). The department-wise details of indices and AQ index are shown in Table: 11. The AQ index of YIC for 2012-13 is 0.591 and except three departments all the other departments could perform better than the college average.

Table: 11 Department wise rating of AQ index, 2012-13

\begin{tabular}{|l|l|l|l|l|}
\hline Department & FA Index & SA Index & IARA Index & AQ Index \\
\hline 1. EIET & 1.000 & 0.952 & 0.685 & 0.879 \\
2. EPET & 0.535 & 0.939 & 0.425 & 0.633 \\
3. GS & 0.332 & 0.916 & 0.683 & 0.644 \\
4. IMT & 0.572 & 0.933 & 0.565 & 0.690 \\
5. MECHATRONICS & 0.000 & 0.000 & 0.000 & 0.000 \\
6. GEOMATICS & 0.143 & 0.785 & 0.262 & 0.397 \\
7. MET & 0.571 & 0.964 & 0.522 & 0.686 \\
8. CHET & 0.925 & 0.979 & 0.761 & 0.888 \\
9. ICT & 0.228 & 0.957 & 0.325 & 0.503 \\
\hline YIC & 0.479 & 0.825 & 0.469 & 0.591 \\
\hline
\end{tabular}

A comparison of departments as per the AQ index showed that CHET department's performance was outstanding with a rating of 0.888 followed by EIET department (0.879). CHET department ranked top for students' achievement and institutional academic resources and accomplishment, whereas EIET department's performance was remarkable for faculty accomplishment. Detailed accounts of departmentwise indices are as demonstrated in Figure: 9. 


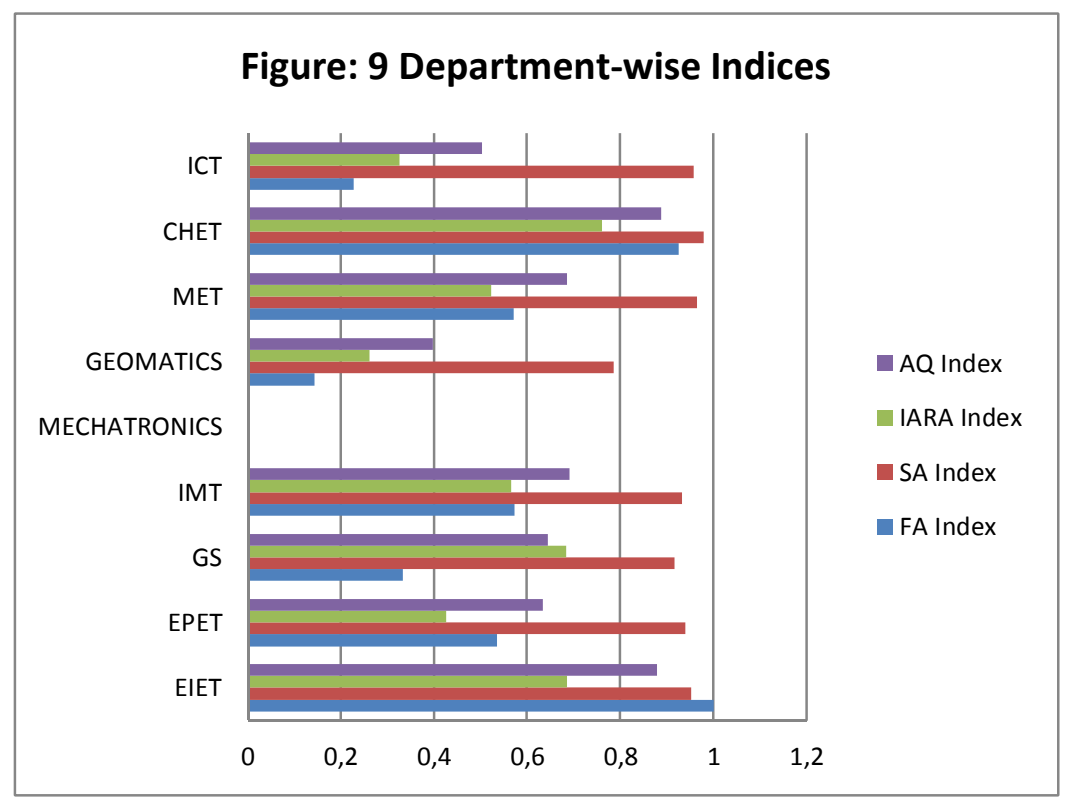

Figure 9: Department-wise Indices

The Academic Quality Indices of YIC is as given in Figure: 10. It could be seen that Students' Achievement was comparatively better than faculty accomplishment, and institutional academic resources and accomplishment. It point to the need for improvement both horizontally at department level and vertically at indicator level. Time series analyses of computing such indices will help the college to compare its progress and develop suitable policies to maintain quality improvement. It will also promote progressive competition among the departments and will lead to quality improvement in academic field.

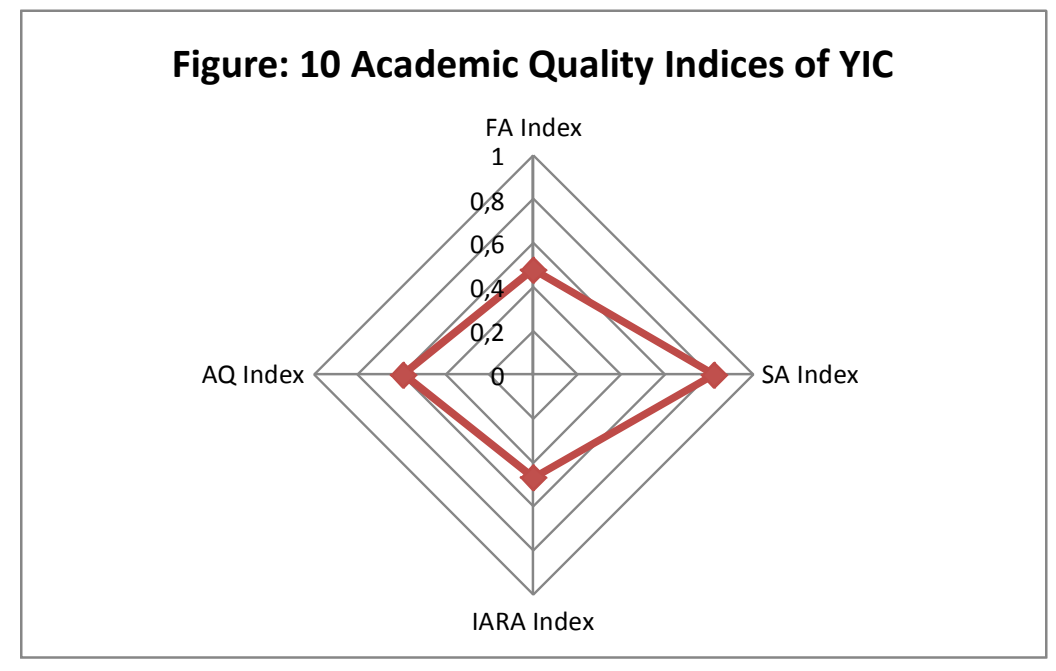

Figure 10: Academic Quality Indices of YIC 


\section{Conclusion}

Academic ranking strategy of Saudi Arabia should give equal emphasis to academic performance, research and all the other academic indicators that we discussed in the foregone sections. The present method of measuring academic quality using 10 important indicators classified under three broad criteria through a composite index is a scientific way of assessing the performance of a college. It will also help in comparison of departments as well as for assessing the year-to-year progress of both college and its departments. The three criteria selected for the present method of quality assessment such as faculty accomplishment, students' achievement, and institutional academic resources and accomplishment are internationally accepted norms of quality assessment as we have seen in the paper. Each criterion has given ample importance to necessary indicators, which is ideally suited to colleges in Middle East countries and in particular Saudi Arabia.

One of the most important criteria of academic performance is the quality of teaching and learning, and as seen in the present model students' achievement is measured in three dimensions such as graduates' success rate, average CGPA, and employability rating. Since there is a direct relationship between educational standards and employability of graduates, the labor market criteria is included as part of the ranking norms. The methodologies applied in the present model including the calculation of indices are purely based on the standard measurement used throughout the world.

The analyses of the department-level data for 2012-13 using the model reveal the following.

YIC's performance on students' achievement is comparatively better than faculty accomplishment and institutional academic resources and accomplishment. It point to the scope for further improvement in faculty accomplishment and institutional academic resources and accomplishment.

Detailed analyses with department-level data on faculty accomplishment reveal that EIET department outpaced all the other departments in publications and projects, followed by CHET and IMT departments. Departments such as Geomatics, MET, EPET, ICT, and Mechatronics need improvement in the area of publications. As regards projects, departments such as ICT, GS, Geomatics, IMT, and Mechatronics need to improve their performance in the forthcoming years.

Analyses of students' achievement with department level data reveal that graduate success rate and CGPA index are highest in IMT department, where as employability rating of graduates in EIET, EPET and MET departments are better than that of other departments. However the Students' Achievement index was highest in CHET department followed by MET and ICT departments.

Institutional academic resources and academic accomplishment rating of CHET department (0.761) was the highest among all departments in 2013-14, followed by EIET and GS departments. As far as professional teachers are concerned further progress is required in recruitment of PhD holders in EPET, Mechatronics, Geomatics and ICT departments. Regarding Student-teacher ratio, improvements 
are required in IMT, Mechatronics and ICT departments. Promotion of community contribution and collaboration are required in EPET, Geomatics, MET, and Mechatronics departments. To maintain academic quality continuous revision of quality assurance is required in all departments. The analyses show that quality assurance and courses/ program development need further enhancement in EPET, GS, MET, and ICT departments.

Even though the paper is an innovative effort to quantify the academic quality of colleges and universities in Saudi Arabia, it is not completely free from limitations. The study is based on data collected from the departments and at least for some indicators the indices may have skewed in favor of some departments. For instance, the faculty accomplishment indicators such as number of publications and projects are generally higher when the numbers of teachers are more and in such cases per head publications/ projects may be a suitable indicator. Students' success rate is assessed in the present study using the pass rate; if data is available the number of students who are admitted in the college got pass after completion of the program may be an ideal indicator in this ground. Geometric average might have been a better tool to calculate the composite index, however the presence of minimum value for some indicators are zero, which may misguide the index scores and that is why simple average is used to calculate the academic quality index.

Maintenance of academic quality being the prime objective of all academic institutions, identification and quantification of suitable criteria are important not only for the concerned educational institutions in marketing its programs but also is a guide post for the students and community in general in the selection of suitable training for human capital formation. The model presented in the paper is an innovative effort in this direction and future research is required for streamlining the model.

\section{References}

Asia Week. (2000). Asia’s Best Universities 2000.

Camilli, G., \& Firestone, W. A, (2000). 'Values and State Ratings: An Examination of the State-by-State Education Indicators in Quality Counts', Educational Measurement: Issues and Practice. Vol.18. No. 4.

CHE. (2007). Your Gateway to the University Ranking. German Centre for Higher Education Development. Clarke, M, (2002). 'News or Noise: An Analysis of US News and World Report's Ranking Scores', Educational Measurement: Issues and Practice. Vol.21. No. 4.

Clarke, M. (2002). 'Some Guidelines for Academic Quality Rankings', Higher Education in Europe, Vol. 27. No. 4.

Institute Of Higher Education, Shanghai Jiao Tong University (IHE-SJTU). (2005). Academic Ranking of World Universities. 
Linn, R., ed. Educational Measurement, 3rd edn. Washington, D.C.: American Council on Education, (1993).

Meredith, M. (2004). 'Why do Universities Compete in the Ratings Game: An empirical Analysis of the Effects of the U.S. News and World Report College Rankings,' Research in Higher Education, Vol. 45.

Merisotis. J. P. (2002). 'Summary Report of the Invitational Roundtable on Statistical Indicators for the Quality Assessment of Higher/tertiary Education Institutions: Ranking and League Table Methodologies', Higher Education in Europe, Vol. 27.

SANOFF, A. (1998). 'Rankings are Here to Stay: Colleges can Improve Them', Chronicle of Higher Education. Vol. 45 No. 2. September.

Siwinski, Perspektywy. W. (2002). 'Ten Years of Rankings,' Higher Education in Europe, Vol. 27.

The Times Higher Education Supplement (THES, 2005), The Times Higher World University Rankings.

Webster, D. S. (1986). Academic Quality Rankings of American Colleges and Universities. Springfield: Charles C. Thomas.

Yanbu Industrial College (YIC, 2013). Academic Catalog- 2012-2013, Kingdom of Saudi Arabia 
Appendix Table: List of Indicators used for Ranking according to the Frequency

\begin{tabular}{|c|c|c|c|c|c|}
\hline \multirow[t]{2}{*}{ Indicators } & \multicolumn{4}{|l|}{ Weights } & \multirow{2}{*}{$\begin{array}{l}\text { Frequency of } \\
\text { the } \\
\text { indicators } \\
(\%)\end{array}$} \\
\hline & Shanghai & Times & CHE* & $\begin{array}{l}\text { Asia } \\
\text { Week }\end{array}$ & \\
\hline $\begin{array}{l}\text { 1.1 Articles on ISI databases } \\
\text { 1.2 Peer review } \\
\text { 1.3 Bibliometric citations per researchers on ISI } \\
\text { databases }\end{array}$ & 20.0 & $\begin{array}{l}40.0 \\
20.0\end{array}$ & & $\begin{array}{l}3.3 \\
20.0\end{array}$ & $\begin{array}{l}50 \% \\
50 \% \\
50 \%\end{array}$ \\
\hline $\begin{array}{l}\text { 2. } 1 \text { Faculty-to-student ratio } \\
\text { 2.2 Students' results (academic performance) }\end{array}$ & & 20.0 & * & 5.0 & $\begin{array}{l}50 \% \\
25 \% \\
\end{array}$ \\
\hline $\begin{array}{l}\text { 3.1 Staff of an institution winning Nobel Prizes } \\
\text { and Fields Medals } \\
\text { 3.2 Articles published in Science and Nature } \\
\text { 3.3 Patents owned by staff }\end{array}$ & 20.0 & & $*$ & & $\begin{array}{l}25 \% \\
25 \% \\
25 \% \\
\end{array}$ \\
\hline $\begin{array}{l}\text { 4.1 Alumni of an institution winning Nobel } \\
\text { Prizes and Fields Medals } \\
\text { 4.2 Recruiters review } \\
\text { 4.3 Size of institution } \\
\text { 4.4 Study location } \\
\text { 4.5 Job market and career-orientation } \\
\end{array}$ & $\begin{array}{l}10.0 \\
10.0\end{array}$ & 10.0 & $\begin{array}{l}* \\
* \\
*\end{array}$ & & $\begin{array}{l}25 \% \\
25 \% \\
50 \% \\
25 \% \\
25 \% \\
\end{array}$ \\
\hline $\begin{array}{l}\text { 5.1 First-year students accepted compared with } \\
\text { total applicants } \\
5.2 \text { Students enrolled compared with accepted } \\
\text { students } \\
5.3 \text { Median score of first-year students in } \\
\text { university entrance test }\end{array}$ & & & & $\begin{array}{l}8.3 \\
8.3 \\
8.3\end{array}$ & $\begin{array}{l}25 \% \\
25 \% \\
25 \%\end{array}$ \\
\hline $\begin{array}{l}\text { 6.1 International students } \\
\text { 6.2 International staff } \\
\text { 6.3 Full-time teachers/researchers with } \mathrm{PhD} \\
\text { degrees } \\
\text { 6.4 Full-time teachers/researchers with master's } \\
\text { and PhD degrees } \\
\text { 6.5 Median pay of teachers/research } \\
\text { 6.6 Per-teacher university spending }\end{array}$ & & $\begin{array}{l}5.0 \\
5.0\end{array}$ & * & $\begin{array}{l}5.0 \\
5.0 \\
5.0 \\
5.0\end{array}$ & $\begin{array}{l}25 \% \\
25 \% \\
50 \% \\
25 \% \\
25 \% \\
25 \%\end{array}$ \\
\hline $\begin{array}{l}\text { 7.1 Articles in peer-reviewed journals } \\
\text { 7.2 Papers presented in international conferences } \\
\text { 7.3 Published books } \\
\text { 7.4 Research funding } \\
\text { 7.5 Graduate students }\end{array}$ & & & * & $\begin{array}{c}3.3 \\
3.3 \\
3.3 \\
3.3 \\
3.3\end{array}$ & $\begin{array}{l}50 \% \\
25 \% \\
25 \% \\
50 \% \\
25 \% \\
\end{array}$ \\
\hline $\begin{array}{l}\text { 8.1 Total spending per student } \\
\text { 8.2 Library spending per student } \\
\text { 8.3 Internet bandwidth } \\
\text { 8.4 Public computers and connection points } \\
\text { 8.5 Laboratory spending } \\
\text { 8.6 Quality of the equipment } \\
\end{array}$ & & & $*$ & $\begin{array}{l}2.0 \\
2.0 \\
2.0 \\
2.0 \\
2.0\end{array}$ & $\begin{array}{l}25 \% \\
25 \% \\
25 \% \\
25 \% \\
25 \% \\
25 \% \\
\end{array}$ \\
\hline 9. Opinion of teachers and students & & & $*$ & & $25 \%$ \\
\hline 10. International orientation (languages) & & & $*$ & & $25 \%$ \\
\hline 11. Academic studies and teaching & & & $*$ & & $25 \%$ \\
\hline
\end{tabular}

* CHE do not have quantified indicators 